\title{
Increasing the renewable energy sources absorption capacity of the Macedonian energy system
}

Boris Ćosić, Nataša Markovska, Verica Taseska, Goran Krajačić, and Neven Duić

Citation: J. Renewable Sustainable Energy 5, 041805 (2013); doi: 10.1063/1.4812999

View online: http://dx.doi.org/10.1063/1.4812999

View Table of Contents: http://jrse.aip.org/resource/1/JRSEBH/v5/i4

Published by the AIP Publishing LLC.

\section{Additional information on J. Renewable Sustainable Energy}

Journal Homepage: http://jrse.aip.org/

Journal Information: http://jrse.aip.org/about/about_the_journal

Top downloads: http://jrse.aip.org/features/most_downloaded

Information for Authors: http://jrse.aip.org/authors

\section{ADVERTISEMENT}
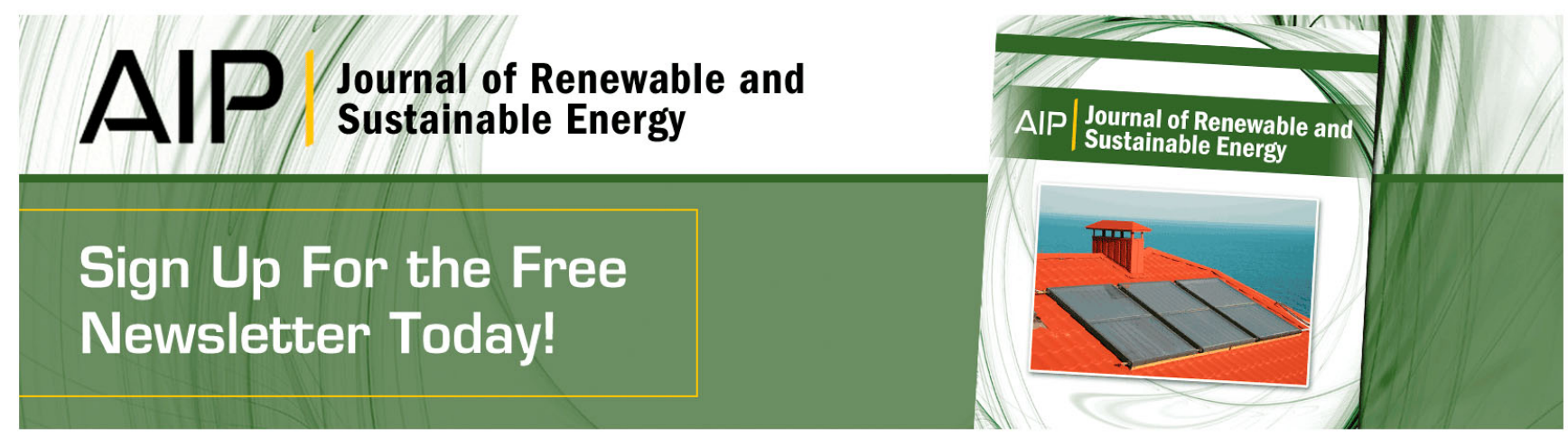


\title{
Increasing the renewable energy sources absorption capacity of the Macedonian energy system
}

\author{
Boris Ćosić, ${ }^{1, a)}$ Nataša Markovska, ${ }^{2}$ Verica Taseska, ${ }^{2}$ Goran Krajačić, ${ }^{1}$ \\ and Neven Duić ${ }^{1}$ \\ ${ }^{1}$ Faculty of Mechanical Engineering and Naval Architecture, University of Zagreb, \\ Ivana Lučića 5, 10002 Zagreb, Croatia \\ ${ }^{2}$ Research Center for Energy, Informatics and Materials, Macedonian Academy of Sciences \\ and Arts, Krste Misirkov 2, 1000 Skopje, Macedonia
}

(Received 31 January 2013; accepted 17 May 2013; published online 3 July 2013)

\begin{abstract}
Macedonian energy sector is the main emitter of greenhouse gases with share of about $70 \%$ in the total annual emissions. Also, $70 \%-75 \%$ of emissions are associated with the electricity generation due to the predominant role of the lignite fuelled power plants. Recently, the government has adopted a strategy for the use of renewable energy sources (RES) which identifies a target of $21 \%$ of final energy consumption from RES by 2020. In this paper, analyses are conducted in order to investigate to which extent and in which way the absorption capacity of the power system for RES electricity can be improved. For this purpose, combining various conventional and RES technologies, including pump storage hydro power plant and revitalisation of the existing lignite power plants six scenarios for the power system expansion are developed by making use of EnergyPLAN model. Critical excess of electricity analyses are conducted in order to identify the maximal penetration of wind electricity. The results have shown that in the exiting capacities maximal penetration of wind electricity in 2020 is $13 \%$ of total electricity consumption. The revitalization of the existing lignite power plants and building of pump storage power plant would increase the wind penetration. Furthermore, the developed scenarios are comparatively assessed in terms of the associated greenhouse gases emissions and import of electricity. (C) 2013 AIP Publishing LLC.
\end{abstract}

[http://dx.doi.org/10.1063/1.4812999]

\section{INTRODUCTION}

Energy production in Macedonia is based mainly on the low-quality domestic lignite, biomass, used mainly for space heating, and hydro, while the share of other renewable energy sources (RES) is very low. ${ }^{1}$ The lignite has been used to meet the base load demand because of low fuel costs, while the hydro has been mainly used to cover peak load. Electricity consumption is characterised by high demand peaks in winter, which are largely due to the use of electric heating to supplement fuelwood heating in the residential sector during very cold periods. ${ }^{2}$ Furthermore, during the latest few years imports of electricity have increased substantially mainly because of rapid increase in electricity demand. ${ }^{3}$ In short, the most important problems the energy sector faces are unfavourable energy mix with high prevalence of lignite, strong dependence on energy import, poor condition of the energy systems and high degree of inefficiency in energy production and use. ${ }^{4}$ All this makes the energy the most important national target sector for implementation of greenhouse gas (GHG) emissions reduction measures. ${ }^{5}$

One of the most promising solutions for alleviation of energy import and diversification of the energy resources, which at the same time reduce the GHG emissions are renewable energy sources. ${ }^{6}$ Importance of the RES in the future energy systems has been also recognised by the

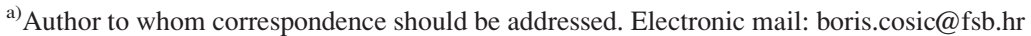


European Union (EU) and its strong and ambitious commitment towards RES together with stable regulatory and market framework has resulted with binding target of at least $20 \%$ renewable energy in final consumption by $2020 .^{7}$ In order to attract investment in the energy sector and to crate stable market framework in the neighbouring countries the regional Treaty between the European Union and nine South East Europe (SEE) partner countries has been signed. ${ }^{8}$ Signing this Treaty, countries which are not members of the EU undertake commitments to implement and apply the EU legislation. ${ }^{9}$ In the case of Macedonia, as one of the signatures of the Treaty, a high degree of convergence with EU law has been achieved ${ }^{10}$ and changes occurred in three key policy sectors have been thoroughly elaborated in Taylor $\mathrm{et} \mathrm{al.}{ }^{11}$

The main problem of RES, except biomass and geothermal, is their intermittent nature, so in order to use them effectively it is necessary to have energy storage in the system ${ }^{12-15}$ and because of the high investment cost in the storage systems, usage of the RES is becoming even more expensive. ${ }^{16,17}$ Furthermore, increase of usage of intermittent renewable energy sources will lead to greater variability in energy generation and to more balancing requirements for the operation of energy system. Analyses conducted in many studies have indicated that wind penetration level and system flexibility are two main factors which have a highest influence on the operation of energy system. ${ }^{18-20}$ In the case of traditional power plants (PP), flexibility can be increased by reducing technical minimum of power plants, on/off cycling time reduction and up/down load ramp increase. ${ }^{19-23}$

The main goal of this paper is to investigate the possibility to increase the RES penetration into Macedonian energy system by improving the flexibility of the thermal power plants-revitalisation of the existing ones and best available technologies for the new ones. Analyses are conducted for high penetration of wind in six different scenarios. The associated benefits of the increased RES penetration, $\mathrm{CO}_{2}$ emissions reduction and electricity import alleviation, are also calculated.

\section{METHODOLOGY}

In order to conduct analysis of a high penetration of the renewables in the energy system of Macedonia, EnergyPLAN model has been used. ${ }^{24}$ EnergyPLAN model is input/output model that performs annual analysis in steps of $1 \mathrm{~h}$. Typical input data are demands, fuel consumption, and different regulation strategies, while the output data are annual production from different energy sources, fuel consumption and $\mathrm{CO}_{2}$ emissions. EnergyPLAN model is specialized in the large scale integration of the renewables in the energy systems, ${ }^{25,26}$ implementation of the storage technologies in the energy systems, ${ }^{27-29}$ implementation of the combined heat and power (CHP) plants in the energy systems, ${ }^{30,31}$ and simulation of the $100 \%$ renewable energy systems. ${ }^{32,33}$

The EnergyPLAN model can be used for technical analysis, market exchange analysis, and feasibility studies. For these analyses, technical regulation and electricity market strategies can be used. The technical regulation strategy-balancing both, heat and electricity demands, has been used in the analysis of the Macedonian energy system. In this strategy, large heat pumps in combination with CHP units are used to minimise export of electricity. Decrease in electricity production from CHP units lead to decrease in heat production which is balanced by increase in the heat produced by the large heat pumps at the CHP plants. Furthermore, the CHP plants during the winter follows heat production while, during the summer period, when the heat demand is very low, CHP plants are working as a condensing plant.

\section{PLANNING OF THE MACEDONIAN ENERGY SYSTEM}

\section{A. Reference energy system}

The reference energy system of Macedonia for the year 2020 has been created by expanding 2008 scenario from Ćosić et al. ${ }^{34}$ Capacities of the power producing units have been obtained from Macedonian Power Company ${ }^{35}$ and from Taseska et al. ${ }^{3}$ Energy consumption and supply data have been taken from International Energy Agency ${ }^{36}$ while hourly wind power production has been calculated by making use of hourly wind speed provided by METEONORM program ${ }^{37}$ for the year 2008. Hourly production data for hydro power plants 
have been obtained from Electricity Transmission System Operator of Macedonia ${ }^{38}$ for the year 2009 while hourly load data for Macedonian power system have been provided by European Network of Transmission System Operators for Electricity (ENTSO-E).$^{39}$ Load curve for hourly district heating demand has been calculated by using degree-day and temperature obtained from METEONORM program.

Macedonian electricity demand and fuel consumption used for reference energy system in the year 2020 have been constituted by data obtained from Macedonian Energy Strategy. ${ }^{1}$ Macedonian electricity demand is expected to rise from $660 \mathrm{ktoe}$ in 2008 to 864 ktoe in 2020, corresponding to an annual rise of $2.5 \%$. Also, expected annual rise of energy demand in the Industrial, Residential, Commercial and Service, Agriculture and Forestry, and Transport sector has been included in the 2020 reference scenario. ${ }^{1}$

Furthermore, fuel prices and $\mathrm{CO}_{2}$ content in the fuels used in the calculation have been obtained from Ćosić et al. ${ }^{19}$ (Table I.)

\section{B. Energy scenarios for Macedonia—closed system calculations}

Analyses for the Macedonia in the year 2020 have been conducted for six different scenarios and closed energy system. In all scenarios, wind electricity production has varied from 0 to 3 TWh. The minimum capacity for the condensing PP is set to $510 \mathrm{MW}$ in five scenarios while in the case of advanced mixed scenario "MIX+", the minimum is set to $230 \mathrm{MW}$.

The first scenario is the "Ref" scenario which considers existing installed capacities in Macedonia with the assumed rise of electricity demand to $10.05 \mathrm{TWh}$.

The second scenario named as photovoltaics based scenario "PV", considers photovoltaic installations of $100 \mathrm{MW}$, while all other data such as electricity, heat, and transport demands are maintained at "Ref" level. Minimum capacity of the power plants is also maintained as in "Ref" scenario.

The third scenario is "CHP" scenario which considers maximal installations of CHP power plants according to Macedonian energy strategy. In this scenario, total capacity of installed CHP plants in Macedonia is increased from 227 MWe to 557 MWe. All other data are maintained as in "Ref" scenario.

The fourth scenario, "hydro power plant (HPP) + pumped hydro storage (PHS)," represents hydro scenario in which all planned hydro power plants from the Macedonian energy strategy are included. In this scenario the capacity of hydro power plants is increased from 528.5 MW to 889.2 MW. Also, new PHS power plant is included. This PHS plant has a pump with capacity of $347.3 \mathrm{MW}$ and a turbine with capacity of $332.8 \mathrm{MW}$.

The fifth scenario, mixed scenario "MIX," considers installations of all power plants from previous scenarios. Assumptions for the "MIX" scenario are:

- The electricity and heat demands are maintained at "Ref" level

- $100 \mathrm{MW}$ of PV are introduced

- The installed capacity of CHP plants is increased from 227 MWe to $557 \mathrm{MWe}$

- The installed capacity of hydro power plants is increased from $528.5 \mathrm{MW}$ to $889.2 \mathrm{MW}$

- 332.8/347.3 MW of PHS power is introduced

- Minimum of condensing PP is set at the $510 \mathrm{MW}$

The sixth scenario, "MIX+," is similar to the previous one, but in this scenario minimum for the condensing PP is set at the $230 \mathrm{MW}$. Detailed description of installed components in six scenarios is given in Table II.

TABLE I. Fuel prices and $\mathrm{CO}_{2}$ content of the fuels used in the calculation.

\begin{tabular}{lccccccc}
\hline \hline & Coal & Fuel oil & Diesel & Petrol & N. gas & LPG & Biomass \\
\hline Fuel prices $(€ / G J)$ & 1.76 & 12.93 & 17.78 & 19.5 & 10.18 & 11.27 & 3.26 \\
$\mathrm{CO}_{2}$ content of fuel $(\mathrm{kg} / \mathrm{GJ})$ & 101.2 & 74 & 74 & 74 & 56.7 & 66.7 & $\ldots$ \\
\hline \hline
\end{tabular}


TABLE II. Installed components in six Macedonian scenarios.

\begin{tabular}{|c|c|c|c|c|c|c|}
\hline \multicolumn{7}{|c|}{ Installed components in the scenarios } \\
\hline Scenarios & $\begin{array}{l}\text { Condensing power } \\
\text { plant (MW) }\end{array}$ & $\begin{array}{l}\text { Hydro power } \\
\text { plant (MW) }\end{array}$ & $\begin{array}{l}\text { Pump hydro } \\
\text { storage (MW) }\end{array}$ & PV (MW) & $\begin{array}{l}\text { Gas fired } \\
\text { CHP (MW) }\end{array}$ & $\begin{array}{c}\text { Power plant } \\
\text { minimum (MW) }\end{array}$ \\
\hline "Ref" & 800 & 528.5 & 0 & 0 & 227 & 510 \\
\hline "PV" & 800 & 528.5 & 0 & 100 & 227 & 510 \\
\hline “CHP” & 800 & 528.5 & 0 & 0 & 557 & 510 \\
\hline "HPP + PHS" & 800 & 889.2 & $332.8 / 347.3$ & 0 & 227 & 510 \\
\hline "MIX" & 800 & 889.2 & $332.8 / 347.3$ & 100 & 557 & 510 \\
\hline "MIX+" & 800 & 889.2 & $332.8 / 347.3$ & 100 & 557 & 230 \\
\hline
\end{tabular}

\section{Optimisation criteria}

In order to design environmental friendly energy system, many different optimisation criteria can be applied. However, unequivocal answer to the often asked question how to design optimal energy system cannot be found. ${ }^{40,41}$

In this study two different optimisation criteria for the maximisation of the penetration of wind electricity in the energy system of Macedonia have been used. In the first case, critical excess of electricity (CEEP) is kept under 5\% (optimisation criteria 1), while in the second case, CEEP is kept under 10\% (optimisation criteria 2) of the wind production. CEEP is the amount of excess electricity produced that could not be used in the energy system. This excess is a result of the mismatch between supply and demand, and the inability of the energy system to absorb the extra electricity. ${ }^{33}$

\section{RESULTS AND DISCUSSION}

The analyses of the EnergyPLAN model are conducted for the closed energy system, which means that the total demand for electricity and heat is covered by own production. Furthermore, it is assumed that at least $30 \%$ of the power at any hour must come from power units capable of supplying ancillary (central power plant, CHP and hydro power plant). ${ }^{18,33}$ Under these assumptions, CEEP is observed (Fig. 1), meaning that the technical regulation strategy used for the balancing between CHP and wind production is not sufficient.

Electricity Excess diagram

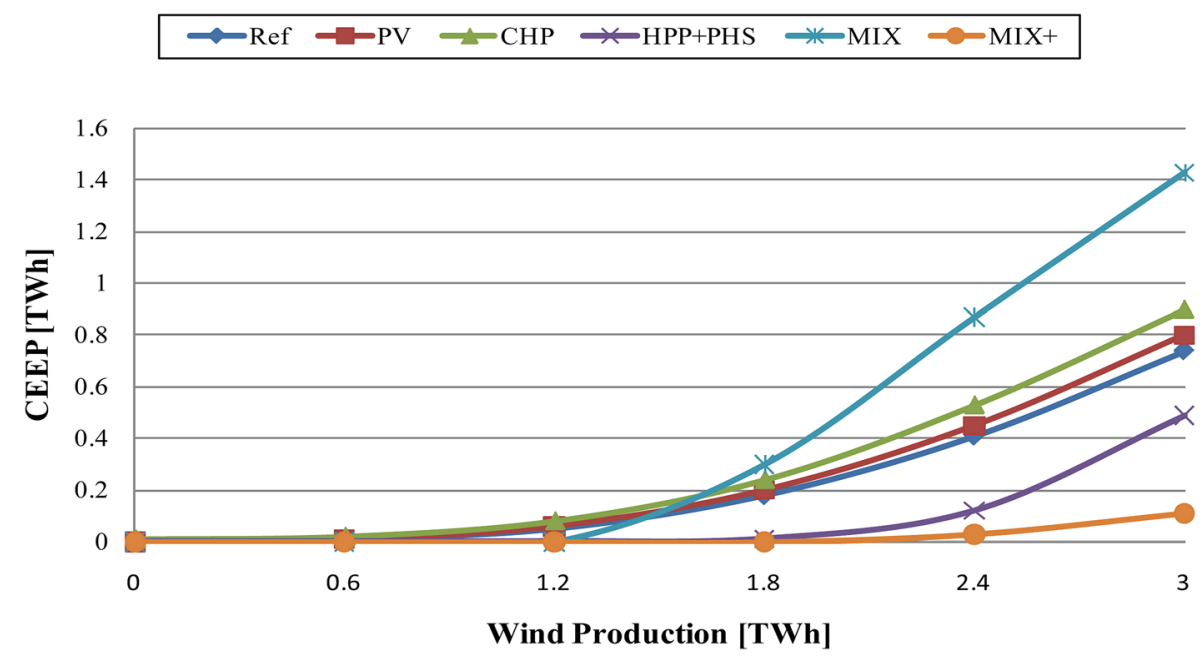

FIG. 1. Excess electricity diagram for Macedonia, 2020. 


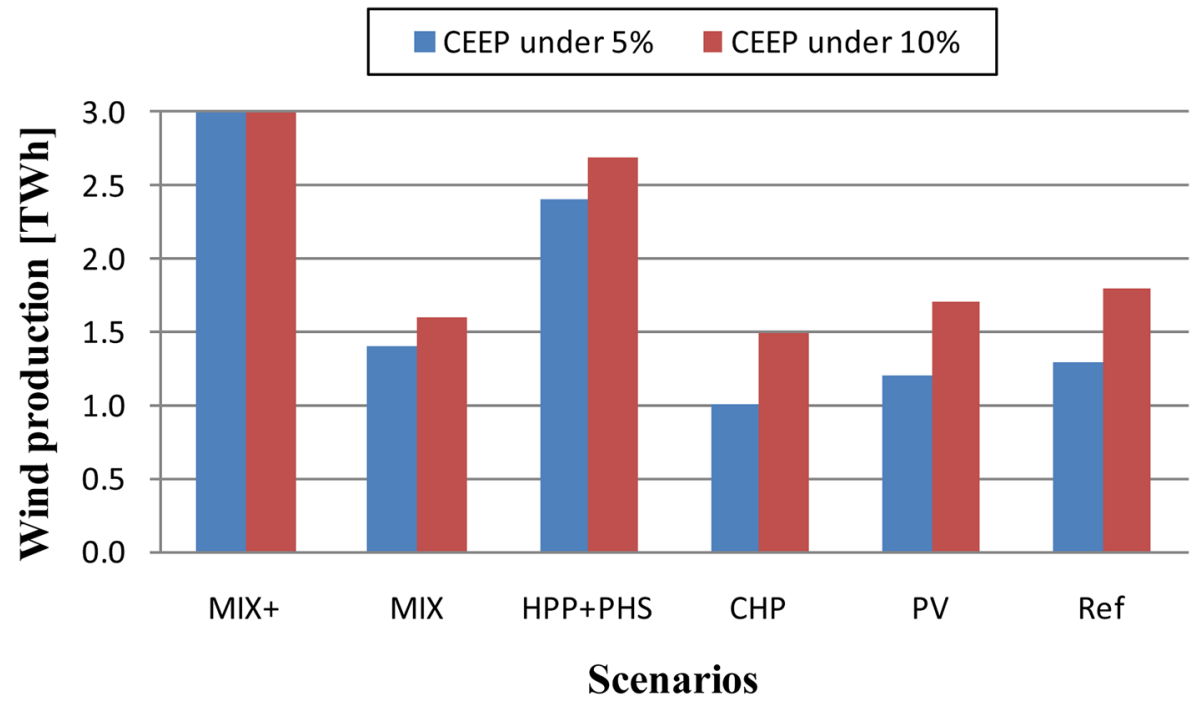

FIG. 2. Maximum wind production in Macedonia for different optimisation criteria.

Analysis conducted for all energy scenarios with results presented in Fig. 1 shows that CEEP can be significantly reduced if a revitalisation of the existing lignite power plants is made, lowering the power plant minimum from $510 \mathrm{MW}$ to $230 \mathrm{MW}$.

The results from the analysis conducted for six different scenarios with the optimisation criteria described above are presented in Fig. 2.

The maximum wind production, critical electricity excess and wind production share of total electricity demand in Macedonia is presented in Table III. The scenario "MIX+" has lowest excess of electricity which is below $0.11 \mathrm{TWh}$ while the "HPP + PHS" scenario represents best option for the maximal wind production if the total investment costs are also taken into consideration.

With the CEEP under 5\%, maximal wind production which Macedonian energy system can accept is $3 \mathrm{TWh}$ with the CEEP of $0.11 \mathrm{TWh}$, corresponding to scenario "MIX+". In "MIX+" scenario, wind production share of the total electricity demand is $30 \%$. In the scenario "HPP + PHS" maximum wind production in the case of the CEEP under 5\% is $2.4 \mathrm{TWh}(24 \%$ share) with the CEEP of 0.12 TWh. In the case of CEEP under $10 \%$ maximum wind production is $2.7 \mathrm{TWh}(27 \%)$ while the CEEP is $0.26 \mathrm{TWh}$. This shows that HPP and PHS have the dominant contribution for improving the wind absorption capacity $(13 \%$ wind penetration in reference scenario is increased to $24 \%$ ). Additional increment of $6 \%$ could be achieved with revitalization of the existing lignite plants.

Results obtained for $\mathrm{CO}_{2}$ emissions reduction in different scenarios by using optimisation criteria are presented in Fig. 3. In this analysis, "No wind" optimisation criteria represent scenarios without wind production. Also, "Max CEEP" in Fig. 3 represents results of analyses

TABLE III. Maximum wind production, CEEP and wind production share in total electricity demand in Macedonia for different optimisation criteria.

\begin{tabular}{lcccccc}
\hline \hline & MIX + & MIX & HPP + PHS & CHP & PV & Ref \\
\hline Wind production $(\mathrm{CEEP}<5 \%)(\mathrm{TWh})$ & 3.00 & 1.40 & 2.40 & 1.00 & 1.20 & 1.30 \\
Wind production $(\mathrm{CEEP}<10 \%)(\mathrm{TWh})$ & 3.00 & 1.60 & 2.70 & 1.50 & 1.70 & 1.80 \\
CEEP $(\mathrm{CEEP}<5 \%)(\mathrm{TWh})$ & 0.11 & 0.06 & 0.12 & 0.05 & 0.06 & 0.07 \\
CEEP $(\mathrm{CEEP}<10 \%)(\mathrm{TWh})$ & 0.11 & 0.16 & 0.26 & 0.15 & 0.17 & 0.18 \\
Wind production share in total electricity demand $(\mathrm{CEEP}<5 \%)(\%)$ & 30 & 14 & 24 & 10 & 12 & 13 \\
Wind production share in total electricity demand $(\mathrm{CEEP}<10 \%)(\%)$ & 30 & 16 & 27 & 15 & 17 & 18 \\
\hline \hline
\end{tabular}




\section{$\mathrm{CO}_{2}$ emissions}

\section{No Wind $\quad$ CEEP under $5 \%$ CEEP under $10 \%$ Max. CEEP}

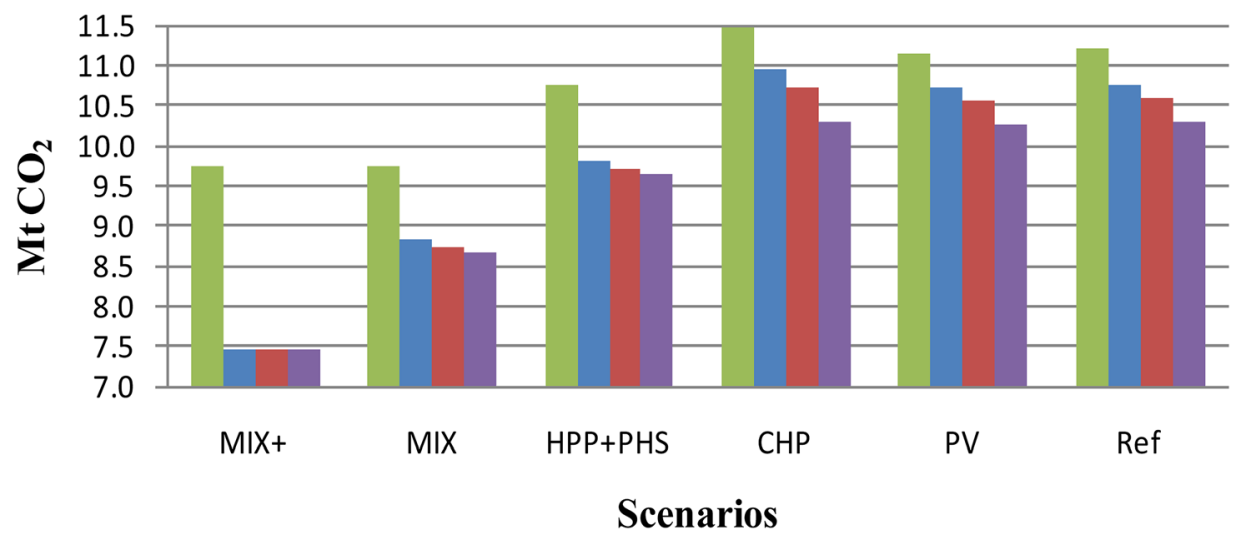

FIG. 3. $\mathrm{CO}_{2}$ emission for six scenarios and different optimisation criteria.

conducted for scenarios with maximum wind production and no optimisation criteria. It is evident that three scenarios ("HPP + HPS," "MIX," and "MIX+") have a lower emissions than the reference scenario since they have installation of new hydro capacities which significantly reduces the emissions. In the "CHP" scenario, $\mathrm{CO}_{2}$ emissions are increased compared to reference scenario because this scenario does not have newly installed technology which can lead to emissions reduction and the electricity demand is covered by the own installed units.

Results presented in Fig. 3 show that combination of the "MIX+" scenario and wind production leads to significant $\mathrm{CO}_{2}$ reduction compared to the reference scenario without wind production. The "MIX+" and "MIX" scenarios are with the lowest $\mathrm{CO}_{2}$ emissions in the case of NO wind production, with emissions of $9.75 \mathrm{Mt}$. "CHP" scenario with total emissions of 11.47 Mt is with the highest $\mathrm{CO}_{2}$ emissions. In the case when the CEEP is kept under $5 \%$ of total wind production, $\mathrm{CO}_{2}$ emissions for the "MIX+" scenario amount 7.47 Mt and for the "CHP" scenario they are $10.95 \mathrm{Mt}$. For the energy systems with maximum wind production and without optimisation, the CEEP is maximal, $\mathrm{CO}_{2}$ emissions for the "MIX+" scenario is 7.47 Mt while in "CHP" scenario these emissions are 10.29 Mt.

The import of electricity is one of the biggest problems for Macedonia. Analysis conducted for six different scenarios shows that the import of electricity can be reduced significantly compared to reference scenario. Results of the analysis are presented in Table IV.

The "MIX+" scenario with $0.06 \mathrm{TWh}$ and "MIX" scenario with 0.04 TWh have the lowest import of electricity while in the "Ref" scenario import of electricity is $0.97 \mathrm{TWh}$. Also, in the case of maximum wind production of 3 TWh, two scenarios (MIX+ and HPP + PHS) can completely satisfy electricity demand of the country. In the case when the CEEP is kept under 5\%, import of electricity in "CHP" scenario is at $0.068 \mathrm{TWh}$ while in the case of "Ref" scenario this import is around $0.5 \mathrm{TWh}$.

TABLE IV. Import of electricity for six scenarios and different optimisation criteria.

\begin{tabular}{lcccccc}
\hline \hline & MIX + & MIX & HPP + PHS & CHP & PV & Ref \\
\hline Scenarios without wind production (TWh) & 0.060 & 0.040 & 0.550 & 0.170 & 0.930 & 0.970 \\
CEEP under 5\% (TWh) & $\ldots$ & $\ldots$ & 0.039 & 0.068 & 0.490 & 0.503 \\
CEEP under 10\% (TWh) & $\ldots$ & $\ldots$ & $\ldots$ & 0.050 & 0.386 & 0.390 \\
Maximum wind production and without CEEP optimisation (TWh) & $\ldots$ & 0.010 & $\ldots$ & 0.016 & 0.212 & 0.243 \\
\hline \hline
\end{tabular}




\section{CONCLUSION}

The results show that the suggested scenarios for the Macedonian energy system with installation of wind power reduce the CEEP, increase the share of renewable energy in the total primary energy supply and save emissions. Furthermore, analyses have shown that HPP and PHS have dominant contribution for improving the wind absorption capacity of the Macedonian power system (13\% wind penetration in reference scenario is increased to $24 \%$ ). Additional increment of $6 \%$ could be achieved with revitalization of the existing lignite plants. Maximal wind production of 3 TWh can be achieved by both optimisation criteria only in the "MIX+" scenario. Also, scenario "MIX+" has the lowest CEEP. Furthermore, in the case without wind production, "MIX+" and MIX scenarios are with the lowest emissions while the highest emissions are associated with the "CHP" scenario. The limitation of the CEEP considerably reduces the import of electricity in CHP scenario compared to "Ref" scenario.

Finally, worth noting is that new storage technologies, such as electric vehicles and heat pumps, will further improve the penetration of renewables, decrease critical excess of electricity and save emissions. The follow-up research should deal with these technologies and quantify the effects of their introduction in the energy system. Also, future research should deal with socio-economic and business-economic aspects because this paper only investigates technical and environmental aspects of wind integration into various energy scenarios.

${ }^{1}$ J. Pop-Jordanov, N. Markovska, A. Krkoleva, and V. Taseska (team members), Strategy for Energy Development in the Republic of Macedonia until 2030 (Government of the Republic of Macedonia, Skopje, 2010).

${ }^{2}$ IEA, Energy in the Western Balkans - The path to reform and Reconstruction (IEA publications, 2008).

${ }^{3}$ V. Taseska, N. Markovska, A. Causevski, T. Bosevski, and J. Pop-Jordanov, Energy 36(4), 2266 (2011).

${ }^{4}$ N. Markovska, V. Taseska, and J. Pop-Jordanov, Energy 34(6), 752 (2009).

${ }^{5}$ N. Markovska, M. Todorovski, T. Bosevski, and J. Pop-Jordanov, in Sustainable Energy Production and Consumption, edited by F. Barbir and S. Ulgiati (Springer Science, 2008), pp. 67-73.

${ }^{6}$ N. K. Sharma and Y. R. Sood, J. Renewable Sustainable Energy 4, 053120 (2012).

${ }^{7}$ European Renewable Energy Council, RE-thinking 2050, A 100\% Renewable Energy Vision for the European Union (European Renewable Energy Council, 2010).

${ }^{8}$ A. Mihajlov, Renewable Sustainable Energy Rev. 14(2), 872 (2010).

${ }^{9}$ S. Padgett, J. Common Market Stud. 49(5), 1065 (2011).

${ }^{10}$ J. Tosun, Energy Policy 46, 417 (2012).

${ }^{11}$ A. Taylor, A. Geddes and C. Lees, The European Union and South East Europe: The Dynamic of Europeanization and Multilevel Governance (Taylor Francis Ltd, United Kingdom, 2012).

${ }^{12}$ G. Krajačić, N. Duić, and M. G. Carvalho, Int. J. Hydrogen Energy 34(16), 7015 (2009).

${ }^{13}$ B. Ć́osić, Z. Stanić, and N. Duić, Energy 36(4), 2017 (2011).

${ }^{14}$ C. Harris, J. P. Meyers, and M. E. Webber, J. Renewable Sustainable Energy 4, 013120 (2012).

${ }^{15}$ J. B. Garrison and M. E. Webber, J. Renewable Sustainable Energy 3, 043101 (2011).

${ }^{16}$ G. Krajačić, N. Duić, A. Tsikalakis, M. Zoulias, G. Caralis, E. Panteri, and M. G. Carvalho, Energy Policy 39(3), 1410 (2011).

${ }^{17}$ G. Krajačić, N. Duić, and M. G. Carvalho, Appl. Energy 88(2), 508 (2011).

${ }^{18}$ L. Hong, H. Lund, and B. Möller, Energy 41(1), 499 (2012).

${ }^{19}$ B. Ćosić, N. Markovska, G. Krajačić, V. Taseska, and N. Duic, Appl. Therm. Eng. 43, 158 (2012).

${ }^{20}$ D. I. Gota, H. Lund, and L. Miclea, Energy 36(11), 6413 (2011).

${ }^{21}$ A. J. Lamadrid and T. Mount, Energy Econ. 34(6), 1959 (2012).

${ }^{22}$ L. Göransson and F. Johnsson, Wind Energy 14(1), 91 (2011).

${ }^{23}$ S. Nikolova, A. Causevski, and A. Al-Salaymeh, Energy Convers. Manage. 65, 697 (2013).

${ }^{24}$ See www.energy.plan.aau.dk/ for "EnergyPLAN - Advanced Energy System Computer Model."

${ }^{25}$ W. Liu, H. Lund, and B. V. Mathiesen, Energy 36(8), 4753 (2011).

${ }^{26}$ I. B. Bjelić, N. Rajaković, B. Ćosić, and N. Duić, "Increasing wind power penetration into the existing Serbian energy system," Energy (in press); http://dx.doi.org/10.1016/j.energy.2013.03.043.

${ }^{27}$ P. A. Østergaard, Energy 37(1), 255 (2012).

${ }^{28}$ D. Connolly, H. Lund, B. V. Mathiesen, E. Pican, and M. Leahy, Renewable Energy 43, 47 (2012).

${ }^{29}$ K. Hedegaard, B. V. Mathiesen, H. Lund, and P. Heiselberg, Energy 47(1), 284 (2012).

${ }^{30}$ H. Lund and A. N. Andersen, Energy Convers. Manage. 46, 893 (2005).

${ }^{31}$ P. A. Østergaard, Energy 35(5), 2194 (2010).

${ }^{32}$ G. Krajačić, N. Duić, Z. Zmijarević, B. V. Mathiesen, A. A. Vučinić, and M. G. Carvalho, Appl. Therm. Eng. 31(13), 2073 (2011).

${ }^{33}$ B. Ćosić, G. Krajačić, and N. Duić, Energy 48(1), 80 (2012).

${ }^{34}$ B. Ćosić, N. Markovska, V. Taseska, G. Krajačić, and N. Duić, Chem. Eng. Trans. 25, 57 (2011).

${ }^{35}$ See http://www.elem.com.mk/en/AnnualReport.asp for "ELEM - Macedonian PowerPlants."

${ }^{36}$ See http://www.iea.org/country/index_nmc.asp for "IEA - International Energy Agency."

${ }^{37}$ See http://www.meteonorm.com/pages/en/meteonorm.php for "METEONORM - Global Meteorological Database for Engineers, Planners and Education." 
${ }^{38}$ See http://www.mepso.com.mk/en-us/ListanjeIzveshtai.aspx?categoryID=138 for "MEPSO - Electricity Transmission System Operator of Macedonia."

${ }^{39} \mathrm{See}$ https://www.entsoe.eu/db-query/country-packages/production-consumption-exchange-package/ for "ENTSO-E European network of transmission system operators for electricity."

${ }^{40}$ P. A. Østergaard, Energy 34(9), 1236 (2009).

${ }^{41}$ R. Segurado, G. Krajačić, N. Duić, and L. Alves, Appl. Energy 88(2), 466 (2011). 